\title{
STRATEGI PROMOSI PADA TOSERBA GANDUNG DAN SOPONGIRO SURABAYA
}

\author{
Ayouvi Poerna Wardhanie \\ Valentinus Roby Hananto \\ Norma Ningsih \\ Dosen Institut Bisnis dan Informatika Stikom Surabaya
}

\begin{abstract}
Along with the development of technology, retail business in society is becoming increasingly important. The retail business is initially seen only limited to providers of goods and services only, is now viewed as a business that is more innovative, dynamic, and competitive. This study is intended for retail store owners and employees to train the design drawings and writings using Adobe Photoshop as a tool to increase sales promotion. The results of these community service is the module manufacturing of Adobe Photoshop, as a guide to make the design drawings, manufacturing of job description framework of each business owner and employee, and the outcome of training design drawings using Adobe Photoshop is used in the media campaign such as t-shirts, banners, posters and billboards.
\end{abstract}

Key Words : Retail Business, Marketing Strategy, Integrated Marketing Communication.

\begin{abstract}
ABSTRAKSI
Seiring dengan berkembangnya teknologi, keberadaan bisnis ritel atau eceran di tengahtengah masyarakat menjadi semakin penting. Bisnis ritel yang semula dipandang hanya sebatas penyedia barang dan jasa saja, sekarang dipandang sebagai bisnis yang semakin inovatif, dinamis, dan kompetitif. Penelitian ini ditujukan bagi pemilik toko bisnis ritel beserta karyawannya untuk melatih mendesain gambar dan tulisan dengan Adobe Photoshop sebagai alat bantu untuk meningkatkan promosi penjualan. Hasil kegiatan dari pengabdian masyarakat ini adalah pembuatan modul Adobe Photoshop sebagai panduan dalam membuat desain gambar, pembuatan kerangka job description dari masing-masing pemilik bisnis dan karyawan, dan hasil pelatihan pembuatan desain gambar menggunakan Adobe Photoshop tersebut digunakan dalam media promosi seperti kaos, banner, poster dan papan reklame.
\end{abstract}

Kata Kunci : Bisnis Retail, Strategi Pemasaran, Komunikasi Pemasaran Terpadu.

\section{PENDAHULUAN}

Kesuksesan finansial sering bergantung pada kemampuan pemasaran. Finansial, operasi, akuntansi dan fungsi bisnis lainnya tidak akan berarti jika tidak ada cukup permintaan akan produk dan jasa sehingga perusahaan bisa menghasilkan keuntungan. Konsep pemasaran muncul pada pertengahan tahun 1950 dimana pemasaran masih memegang filosofi "membuat dan menjual" yang berpusat pada produk, tetapi saat ini bisnis beralih filosofi menjadi "merasakan dan merespon" yang berpusat pada pelanggan. Tugas pemasaran saat ini bukanlah mencari pelanggan yang tepat untuk perusahaan, melainkan menemukan produk yang tepat untuk pelanggan perusahaan. Strategi pemasaran yang bagus dapat gagal diwujudkan akibat implementasi yang buruk. Jika perusahaan memutuskan untuk mempertahankan kepemimpinan teknologinya, perusahaan itu harus merencanakan program untuk memperkuat departemen R\&Dnya, mengumpulkan intelijen teknologi, mengembangkan produk canggih, melatih wiraniaga teknik dan mengembangkan iklan untuk mengomunikasikan kepemim-pinan teknologinya. Dunia bisnis saat ini menyadari bahwa jika mereka tidak memperlakukan pihak berkepentingan (stakeholder) dengan baik, misalnya pelanggan, karyawan, pemasok, distributor mereka mungkin tidak akan pernah menghasilkan laba yang cukup bagi perusahaannya (Rayana, 2009).

Seiring dengan berkembangnya teknologi, keberadaan bisnis ritel atau eceran di tengah-tengah masyarakat menjadi semakin penting. Hal ini terjadi karena adanya perubahan pola belanja masyarakat yang semakin selektif dan adanya perbedaan cara pandang masyarakat tentang bisnis ritel (eceran). Mailool dalam (Paramita, 2012) menjelaskan bahwa perubahan gaya hidup masyarakat Indonesia yang didukung oleh meluasnya penggunaan kartu kredit mendorong kebutuhan ritel modern semakin meningkat. Perkembangan gaya hidup tersebut sejalan dengan tumbuhnya mal-mal yang sangat mendukung tumbuhnya ritel modern, sehingga terjadi tren modernisasi pola hidup konsumen di Indonesia. Bisnis ritel yang semula dipandang hanya sebatas penyedia 
barang dan jasa saja, sekarang dipandang sebagai bisnis yang semakin inovatif, dinamis, dan kompetitif. Saat ini, membanjirnya usaha minimarket modern seperti Alfamart dan Indomart tentu akan mengancam bisnis pemilik ritel tradisional. Seperti yang kita ketahui bahwa persaingan usaha adalah sebuah realita dan memang hal yang tidak dapat terelakkan dalam menjalankan usaha, dan salah satu hal yang harus dilakukan dan menjadi perhatian terpenting adalah mempersiapkan strategi yang lebih baik dalam mengatasi hal tersebut. Dengan semakin maraknya minimarket dan supermarket di Indonesia, khususnya di Surabaya salah satu toserba yang terkena dampak dari persaingan sengit tersebut adalah Toserba Gandung dan Sopongiro.

Toserba Gandung menjual berbagai macam produk kebutuhan mulai dari rumah tangga, sembako, alat tulis, listrik hingga mainan anak-anak. Meskipun tergolong tradisional tetapi Toserba Gandung dapat dikatakan cukup modern karena telah menggunakan CCTV di dalam tokonya, serta memiliki aplikasi penjualan untuk memudahkan pemilik mengecek persedian barang, mengenai barang mana yang laku terjual dan tidak, jumlah barang keluar dan lain-lain. Jumlah tenaga kerja di Toserba Gandung sebanyak empat orang, dimana satu orang sebagai kasir dan tiga orang mobile untuk melayani pelanggan, menata dan mengisi barang-barang di rak dan melakukan order ke supplier. Strategi penjualan yang digunakan oleh Toserba Gandung masih terbilang tradisional dibandingkan dengan minimarket seperti Indomart atau Alfamart, mereka masih mengandalkan strategi Low Cost Leadership dan promosi mouth to mouth dengan lingkungan sekitar.

Hampir sama dengan Toserba Gandum, Toserba Sopongiro juga menjual berbagai macam produk kebutuhan mulai dari rumah tangga, alat tulis, mainan anak-anak, gas elpiji hingga saat ini memperluas usahanya dengan membuka jasa laundry. Toserba Sopongiro belum dilengkapi dengan teknologi CCTV serta belum memiliki aplikasi penjualan untuk memudahkan pemilik mengecek persedian barang, sehingga proses pengecekan masih dilakukan secara manual. Jumlah tenaga kerja di Toserba Sopongiro sebanyak dua orang yang sekaligus merupakan pemilik toko tersebut, dimana satu orang sebagai kasir dan satu orang bergerak untuk melayani pelanggan, menata dan mengisi barang-barang di rak dan melakukan order ke supplier. Strategi penjualan yang digunakan oleh Toserba Sopongiro masih tradisional, dimana masih mengandalkan strategi Low Cost Leadership dan promosi mouth to mouth dengan lingkungan sekitar.

Kendala dalam hal promosi yang masih sederhana serta kurangnya pengetahuan tentang analisa penjualan tersebut membuat performa Toserba Gandung dan Toserba Sopongiro belum maksimal. Oleh sebab itu, dalam pengabdian masyarakat ini pengusul mencoba melakukan terobosan baru yaitu peningkatkan ketrampilan / skill pengusaha dalam memanfaatkan media promosi misalnya banner, brosur dan media sosial. Selain itu pengusul juga memberikan pelatihan dalam membuat desain promosi dengan bantuan Adobe Photoshop dan pelatihan pemanfaatan media promosi sebagai pendukung keputusan promosi penjualan

\section{TINJAUAN PUSTAKA \\ Bisnis Retail (Eceran)}

Berbagai definisi dan pengertian bisnis ritel atau perdagangan eceran telah dibuat oleh para ahli manajemen dan bisnis. (Shofiah, 2000) menyatakan: "Retaling atau sistem perdagangan eceran merupakan tahapan terakhir dalam proses penyaluran barang yang membentuk bisnis dan orangorang yang terlibat dalam suatu pergerakkan fisik maupun transfer kepemilikan antara barang dan jasa dari produsen ke pelanggan". (Kotler \& Armstrong, Dasar-Dasar Pemasaran, 1998) menyatakan perdagangan eceran (retailing) meliputi semua aktivitas yang dilakukan untuk menjual barang atau jasa langsung kepada konsumen akhir bagi penggunaan pribadi dan bukan untuk bisnis.

Seorang pebisnis atau pedagang eceran harus memiliki kepekaan terhadap kebutuhan dan keinginan dari konsumen. Seringkali diperlukan perubahan kebijakan dan strategi dari pihak pedagang untuk mengantisipasi perkembangan dan perubahan keinginan atau kebutuhan konsumen. Informasi dari pemerintah, buku-buku dan laporan bisnis lainnya diperlukan dalam mengembangkan bisnis eceran. Konsep yang mendukung sukesnya usaha seseorang dalam bisnis eceran yaitu menerapkan enam prinsip, menjual barang yang tepat (the right item), dengan tempat yang tepat (in the right place), pada waktu yang tepat (at the right time), jumlah yang tepat (in the right quantity) dan harga yang sesuai (at the right price) dan pelayanan yang memuaskan (with the right service) (Medyawati \& dkk, 2000). Bisnis ritel terbagi dalam berbagai jenis yang sangat beragam berdasarkan klasifikasi menurut bentuk, ukuran, dan tingkat modernitasnya. Berdasarkan tingkat modernitas, bisnis ritel 
dapat diklasifikasikan dalam ritel tradisional dan ritel modern. Klasifikasi tersebut umumnya dipersempit pengertiannya hanya pada in-store retailing yaitu bisnis ritel yang menggunakan toko untuk menjual barang dagangannya. Termasuk regulasi pemerintah mengenai bisnis ritel cenderung menggunakan pendekatan tersebut. Perpres No 112 Tahun 2007 tentang Penataan dan Pembinaan Pasar Tradisional, Pusat Perbelanjaan dan Toko Modern, memberikan batasan pasar tradisional dan toko modern dalam pasal 1 sebagai berikut:

a. Pasar Tradisional adalah pasar yang dibangun dan dikelola oleh Pemerintah, Pemerintah Daerah, Swasta, Badan Usaha Milik Negara dan Badan Usaha Milik Daerah termasuk kerjasama dengan swasta dengan tempat usaha berupa toko, kios, los dan tenda yang dimiliki/dikelola oleh pedagang kecil, menengah, swadaya masyarakat atau koperasi dengan usaha skala kecil, modal kecil dan dengan proses jual beli barang dagangan melalui tawar menawar.

b. Toko Modern adalah toko dengan sistem pelayanan mandiri, menjual berbagai jenis barang secara eceran yang berbentuk Minimarket, Supermarket, Department Store, Hypermarket ataupun grosir yang berbentuk Perkulakan.

Pakar pemasaran dunia (Kotler P. , 1997) memberikan gambaran lebih utuh dengan membagi perdagangan eceran menjadi pengecer toko (store retailing), penjualan eceran tanpa toko (nonstore retailing), dan berbagai organisasi eceran (retail organizations).

1. Pengecer Toko (Store Retailing), jenisjenisnya adalah: toko khusus (specialty stores); toko serba ada (deparment stores); pasar swalayan (supermarkets); toko kelontong (convenient stores); toko diskon (discount stores); pengecer potongan harga (off-price retailers) terdiri dari toko pabrik (factory outlets), pengecer potongan harga independen (independent offprice retailers), dan klub gudang (warehouse clubs)/ klub grosir (wholesale clubs); toko super (superstores) terdiri dari toko kombinasi (combination store) dan pasar hiper (hypermarket); dan ruang pamer katalog (catalog showrooms).

2. Penjualan Eceran Tanpa Toko (Nonstore Retailing), jenis-jenisnya adalah: penjualan langsung (direct selling), terdiri dari penjualan satu-satu (one-toone selling), penjualan satu kebanyak/ pesta (one-to-many (party) selling), pemasaran bertingkat/ jaringan (multilevel (network) marketing); pemasaran langsung (direct marketing), termasuk di dalamnya pemasaran lewat telepon (telemarketing), pemasaran tanggapan langsung lewat televisi (program home shopping dan infomercials), dan belanja elektronik: penjualan otomatis (automatic vending): dan jasa pembelian (buying service).

3. Organisasi Eceran (Retail Organizations), jenis-jenisnya adalah: jaringan toko korporat (corporate chain stores); jaringan sukarela (voluntary chain); koperasi pengecer (retailer cooperative); koperasi konsumen (consumer cooperative); organisasi waralaba (franchise organization); dan konglomerat perdagangan (merchandising conglomerate).

\section{Persaingan Bisnis Ritel}

Persaingan bisnis ritel berada dalam lingkup lingkungan industri dan individual. Keragaman jenis bisnis ritel juga membawa implikasi adanya persaingan pada jenis ritel yang sama dan pada sesama bisnis ritel dari kelas yang berbeda. Bahkan, pembahasan persaingan bisnis ritel menjadi lebih menarik dengan memasukkan persaingan antar supplier. Persaingan antar supplier meskipun bukan merupakan salah satu jenis bisnis ritel, namun dalam lingkungan industri bisnis ritel, supplier memiliki relevansi kuat untuk memberi corak dinamika persaingan bisnis ritel (Utomo, 2010). (Tambunan \& dkk, 2004) dalam penelitian mengenai persaingan bisnis ritel di Jakarta, menyatakan bahwa persaingan dalam industri retail yang ada di Jakarta dapat dilihat dari berbagai segi, yaitu persaingan antara retail modern dan tradisional, persaingan antar sesama retail modern, persaingan antar sesama retail tradisional, dan persaingan antar supplier.

Menurut pakar retail Koestarjono Prodjolalito dalam (Tambunan \& dkk, 2004), permasalahan utama antara retail modern (minimarket, supermarket dan hypermarket) dan retail tradisional, terutama di kota-kota besar seperti Jakarta adalah lokasi, di mana retail modern dengan kekuatan modalnya yang luar biasa berkembang begitu pesat yang lokasinya berdekatan dengan lokasi retail tradisional yang sudah lebih dulu berada di lokasi tersebut. Regulasi mengenai pengaturan lokasi bagi retail modern sudah dibuat baik melalui peraturan dari pemerintah pusat maupun pemerintah daerah. Jarak minimum antara retail modern dengan retail tradisional biasanya sudah ditentukan untuk memberi 
kesempatan bagi pasar-pasar tradisional untuk tetap bisa mendapatkan pembeli dari masyarakat sekitar pasar tersebut. Namun kenyataannya masih banyak ditemukan ritel modern yang didirikan berdekatan atau bahkan bersebelahan dengan ritel tradisional. Persaingan antara ritel modern dan ritel tradisional semakin tidak seimbang dengan adanya jam buka ritel modern (terutama minimarket) yang panjang, bahkan hingga 24 jam penuh. Kelebihan lain ritel modern adalah kondisi yang nyaman, kebersihan yang terjaga, berkesan elit, pelayanan bagus, dan barang-barang yang dijual murah, lengkap, dan berkualitas.

Dalam hal persaingan antara sesama retail tradisional, penelitian diatas menyebutkan bahwa berbeda dengan retailer modern yang dalam menentukan lokasinya selalu mempertimbangkan banyaknya konsumen, accessibility dan feasibility, bagi retail tradisional, lokasi tidaklah mempengaruhi omzet penjualan perharinya. Masing-masing pedagang tradisional sudah mempunyai pelanggan sendiri. Tidak adanya kesepakatan harga di antara para pedagang, menimbulkan persaingan di antara mereka sehingga mereka berusaha dengan caranya sendiri untuk menggaet pelanggan. Selanjutnya, penelitian diatas memasukkan persaingan antar supplier, baik yang dilakukan oleh produsen langsung maupun oleh agen, dalam kajian persaingan bisnis ritel. Persaingan yang terjadi antar supplier adalah persaingan dalam memberikan keuntungan bagi ritel. Namun, ternyata persaingan tersebut hanya ditemukan dalam kaitannya dengan ritel modern. Salah satu penyebabnya adalah karena lemahnya posisi tawar (bargaining position) para supplier terhadap pengusaha ritel modern. Ritel modern biasanya menerapkan aturan yang ketat atas kemungkinan suatu produk bisa diterima, sementara banyak supplier yang ingin memasok produknya ke ritel modern. Ritel modern juga biasa menekan harga dari supplier agar harga jualnya nanti bisa dibuat sesuai keinginan retailer. Supplier yang bisa memenuhi keinginan retailer dan menyisihkan supplier-supplier yang lain yang akhirnya bisa memasok produknya ke ritel modern.

\section{Strategi Promosi}

Strategi promosi menurut (Lamb, 2009), "Strategi promosi adalah rencana untuk penggunaan yang optimal dari elemen-elemen promosi: periklanan, hubungan masyarakat, penjualan pribadi, dan promosi penjualan". Menurut (Kotler \& Armstrong, Marketing management (14th ed.), 2012), Promosi adalah suatu unsur yang digunakan untuk memberitahukan dan membujuk pasar tentang produk atau jasa yang baru pada perusahaan melalui iklan, penjualan pribadi, promosi penjualan, maupun publikasi. (Kotler \& Armstrong, Marketing management (14th ed.), 2012) mendefinisikan bauran promosi (promotion mix) sebagai perpaduan spesifik alat-alat promosi yang digunakan perusahaan untuk mengkomunikasikan value ke customer secara persuasif dan membangun customer relationships.

Menurut (Hedynata \& Radianto, 2016) Bauran promosi (promotional mix) terdiri dari 8 model dirangkum dari buku Kotler dan Keller (2012:498-501); Kotler dan Armstrong (2012:408), yaitu:

1. Iklan/ Advertising merupakan semua bentuk terbayar dari persentasi nonpersonal dan promosi ide, barang atau jasa melalui sponsor yang jelas melalui media cetak (koran dan majalah), media penyiaran (radio dan televisi), media jaringan (telepon, kabel, satelite, wireless), dan media elektronik (rekaman suara, rekaman video, CD-ROM, halaman website), dan media pameran (billboard, papan petunjuk, dan poster).

2. Promosi Penjualan/Sales Promotion, merupakan berbagai insentif jangka pendek untuk mendorong percobaan atau pembelian produk atau jasa termasuk promosi konsumen (seperti sampel, kupon, dan premi), promosi perdagangan (iklan dan tunjangan), dan bisnis dan promosi tenaga penjualan (kontes untuk reputasi penjualan).

3. Acara dan Pengalaman/ Even and Experiences merupakan kegiatan dan program yang disponsori perusahaan yang dirancang untuk menciptakan interaksi harian atau merek khususterkait interaksi dengan konsumen, termasuk seni olahraga, hiburan, dan menyebabkan acara atau kegiatan menjadi kurang formal.

4. Hubungan Masyarakat dan Publisitas/ Public Relations and Publicity merupakan berbagai program yang diarahkan secara internal kepada karyawan dari perusahaan atau konsumen luar, perusahaan lain, pemerintah, dan media untuk mempromosikan, membangun hubungan antar perusahaan dengan publik , melindungi dan membangun citra perusahaan atau produk komunikasi individu yang positif.

5. Penjualan Personal/ Personal Selling, merupakan interaksi tatap muka yang 
dilakukan oleh tenaga penjualan perusahaan dengan satu atau lebih pembeli prospektif untuk tujuan melakukan pertemuan penjualan, presentasi pribadi, menjawab pertanyaan, pengadaan pesanan, membuat penjualan, dan hubungan pelanggan.

6. Pemasaran Langsung/ Direct Marketing merupakan penggunaan surat, telepon, facsimile, e-mail, atau internet untuk berkomunikasi atau berhubungan secara langsung dengan meminta respon atau tanggapan dan melakukan dialog dari pelanggan dan prospek tertentu.

7. Pemasaran Interaktif/ Interactive Online Marketing adalah kegiatan dan program online yang dirancang untuk melibatkan pelanggan atau prospek dan secara langsung atau tidak langsung meningkatkan kesadaran memperbaiki citra, atau menciptakan penjualan produk dan jasa.

8. Pemasaran dari mulut ke mulut/ Word of Mouth Marketing, merupakan komunikasi lisan, tertulis, dan elektronik antar masyarakat yang berhubungan dengan keunggulan atau pengalaman membeli atau menggunakan produk atau jasa.

Tujuan utama promosi adalah memberi informasi, menarik perhatian dan untuk selanjutnya memberi pengaruh terhadap meningkatnya penjualan. Suatu kegiatan promosi jika dilaksanakan dengan baik dapat mempengaruhi konsumen mengenai dimana dan bagaimana konsumen membelanjakan pendapatannya. Promosi berusaha agar demand tidak elastis (Buchari, 2008).

\section{METODE PELAKSANAAN}

\section{Metode Pendekatan yang Ditawarkan}

Dalam rangka mencapai tujuan pengembangan usaha dengan objek Toserba Gandung dan Sopongiro Surabaya, maka ditempuh langkah-langkah sebagai berikut :

1. Mengadakan pelatihan desain gambar dengan bantuan aplikasi Adobe Photoshop, misalnya pembuatan poster, banner, brosur dan lainnya.

2. Melakukan diskusi atau sharing tentang peningkatan brand awareness toko mitra dengan memanfaatkan media promosi, seperti pemasangan papan reklame yang berisikan informasi penting tentang produk atau kegiatan toserba serta bagaimana cara dalam membuat job description yang baik untuk sumber daya manusia dalam toserba tersebut.

Pelatihan dilakukan selama kurang lebih 5 kali pertemuan dimana pertemuan pertama berupa pengenalan anggota tim beserta diskusi singkat tentang profil toko, perkembangan toko saat ini dan kendala apa saja yang dihadapi. Pertemuan kedua sampai kelima akan dilakukan pemberian materi berupa penggunaan Adobe Photoshop serta materi pemanfaatan media promosi yang sedang tren saat ini. Pelaksanaan pelatihan telah disepakati oleh pihak toko mitra yaitu pada bulan Oktober sampai dengan November. Dalam kesepakatan tersebut, pemilik toko juga menginginkan adanya tambahan materi tentang job description yang ada di dalam struktur toko retail, seperti tugas dan tanggung jawab kepala toko, kasir, pramuniaga, logistik dan lainnya. Hal ini dilakukakan mengingat para karyawan masih sangat awam dan kesulitan dalam memahami tugas dan tanggung jawab pekerjaannya.

\section{REALISASI PELAKSANAAN}

Kegiatan pelatihan desain gambar menggunakan Adobe Photoshop ini telah dilaksanakan pada tanggal 30 September -4 November 2016, dengan perincian jadwal dan materi sebagai berikut:

Tabel 1. Jadwal Pelaksanaan Pelatihan Desain Gambar Adobe Photoshop di Toserba Sopongiro dan Gandung Surabaya

\begin{tabular}{|c|c|c|c|c|}
\hline Tanggal & Waktu & Materi & Pertemuan & Penyaji \\
\hline $\begin{array}{l}30 \text { September } \\
2016\end{array}$ & $18.00-19.30$ & $\begin{array}{l}\text { Pengenalan dasar-dasar Adobe } \\
\text { Photoshop kepada mitra toko } \\
\text { Sopongro Surabaya }\end{array}$ & 1 kali & $\operatorname{Tim}$ \\
\hline 7 Oktober 2016 & $16.00-18.30$ & $\begin{array}{l}\text { Pengenalan dasar-dasar Adobe } \\
\text { Photoshop kepada mitra toko } \\
\text { Gandung Surabaya } \\
\end{array}$ & 1 kali & $\operatorname{Tm}$ \\
\hline $\begin{array}{c}10-14 \text { Oktober } \\
2016\end{array}$ & $18.00-19.00$ & $\begin{array}{l}\text { Pengetahuan berupa teknik } \\
\text { lanjut pada photoshop } \\
\text { (pindah foto, edit foto dll) dit } \\
\text { toko Sopongiro Surabaya }\end{array}$ & $3 \mathrm{kali}$ & Tim \\
\hline $\begin{array}{l}17-21 \text { Oktober } \\
2016\end{array}$ & $18.00-19.00$ & $\begin{array}{l}\text { Pengeteahuan berupa teknik } \\
\text { lanjut pada photoshopp } \\
\text { (pindah foto, edit foto dII) di } \\
\text { toko Gandung Surabaya }\end{array}$ & 3 kali & $\operatorname{Tim}$ \\
\hline 28 Oltober 2016 & $18.00-19.00$ & \begin{tabular}{|l|} 
Pembuatan poster hasil \\
pelathan di toko Soppogiro \\
Surabaya
\end{tabular} & 1 kali & Tim \\
\hline 4 November 2016 & $16.00-17.30$ & \begin{tabular}{|l|}
$\begin{array}{l}\text { Pembuatanposter hasil } \\
\text { pelatihan di toko Gandung } \\
\text { Surabaya }\end{array}$ \\
\end{tabular} & 1 kali & Tim \\
\hline
\end{tabular}

\section{Sasaran Pelaksanaan}

Peserta pelatihan adalah pemilik toko dan karyawan dari masing-masing mitra yang berjumlah 4 orang. Adapun rincian dari peserta pelatihan akan dijelaskan pada tabel dibawah ini.

Tabel 2. Peserta Pelatihan Desain Gambar Adobe Photoshop

\begin{tabular}{|c|c|c|}
\hline Nama Toko & Pemilik & Karyawan \\
\hline Sopongiro & 1 & 0 \\
\hline Gandung & 1 & 2 \\
\hline
\end{tabular}

LOKASI DAN WAKTU KEGIATAN 
Program pengabdian pada masyarakat ini dilaksanakan di Toserba Sopongiro dan Toserba Gandung Surabaya. Kegiatan dilaksanakan mulai tanggal 30 September - 4 November 2016. Pelatihan dilakukan selama lima kali pertemuan dengan waktu kurang lebih satu setengah jam setiap pertemuan.

\section{PEMBAHASAN}

Hasil yang telah dicapai dalam pelaksanaan pengabdian masyarakat di dua mitra, yaitu Toserba Gandung dan Toserba Sopongiro Surabaya adalah pembuatan modul desain gambar Adobe Photoshop, yang sudah dilengkapi dengan tutorial per tahapan dengan terstruktur sehingga dapat dipahami dengan mudah oleh para pemilik bisnis toko retail maupun karyawannya. Disamping itu, kami juga telah mempersiapkan hasil gambar dari penggunaan Adobe Photoshop yang telah kami kerjakan sendiri sebagai contoh nyata, bahwa dengan mempelajari tools ini akan menambah ilmu, kreatifitas dan skill pemilik sekaligus karyawan toko dalam meningkatkan promosi penjualan toko mereka.

\section{FAKTOR PENDUKUNG}

Faktor yang ikut mendukung terlaksananya pelatihan ini adalah adanya dukungan program dan dana dari Institut Bisnis dan Informatika Stikom Surabaya yang terwadahi dalam program Pengabdian pada Masyarakat. Faktor lain yang sangat penting adalah respon positif dari mitra Toserba Gandung dan Toserba Sopongiro Surabaya yang menyambut baik program ini. Demikian juga antusiasme karyawan dan pemilik dalam mengikuti pelatihan yang begitu tinggi. Dari sisi fasilitas, kesediaan pemilik toserba dalam menyediakan tempat di toko tersebut sangat membantu terlaksanannya pelatihan ini. Hal ini besar pengaruhnya bagi keberhasilan pelatihan. Dari sisi tim pelatih, ketersediaan tenaga ahli dari Jurusan Sistem Informasi dan Manajemen Bisnis merupakan faktor yang sangat membantu suksesnya kegiatan ini.

\section{FAKTOR PENGHAMBAT}

Tidak ada hambatan besar yang mengganggu dalam pelaksanaan pelatihan ini. Hambatan yang ada antara lain tingkat kemampuan pemakaian laptop dari karyawan dan pemilik toko yang sangat bervariasi. Hal ini dikarenakan karyawan maupun pemilik toserba jarang menggunakan laptop sebagai alat dalam pembuatan desain gambar serta belum pernah mendapatkan pengetahuan tentang Adobe Photoshop. Disamping itu, faktor waktu dalam melakukan pelatihan yang sangat minim. Hal ini diakibatkan oleh keterbatasan tim pelatih dan mitra toko dalam mengatur jadwal pelatihan, dikarenakan kesibukan masing-masing orang. Oleh sebab itu ukuran keberhasilan dari pelatihan desain gambar dan tulisan menggunakan Adobe Photoshop ini hanya sampai pada tahap pengenalan dasar-dasar Adobe Photoshop dan pembuatan desain promosi bagi mitra toko.

\section{EVALUASI}

Kemauan yang keras dari peserta pelatihan merupakan indikator awal keberhasilan pelatihan desain gambar dan tulisan menggunakan Adobe Photoshop. Indikator lain yang sangat menggembirakan adalah peserta yang belum pernah menggunakan laptop sebelumnya, setelah pelatihan menunjukkan kemampuan untuk mengoperasikan laptop dan bahkan mampu membuat desain gambar dan tulisan menggunakan Adobe Photoshop. Namun demikian dalam pelatihan ini belum semua peserta menguasai secara optimal, dikarenakan oleh faktor usia dan jarang berlatih menggunakan Adobe Photoshop. Oleh sebab itu para peserta menginginkan agar diadakan pelatihan-pelatihan lanjutan.

\section{KESIMPULAN DAN SARAN}

Pada pelatihan ini telah dilakukan beberapa persiapan yaitu, modul pelatihan untuk peserta dan trainer. Pelatihan dilaksanakan pada bulan September sampai dengan November 2016, hal ini dikarenakan jadwal pelatihan menyesuaikan kondisi mitra. Kegiatan pelatihan ini dilaksanakan selama 5 kali pertemuan, mulai jam 18.00 sampai dengan jam 19.30 (1,5 jam). Setelah dilakukan pengamatan, indikator keberhasilan yang telah dicapai dalam pelatihan ini, adalah:

$$
\text { 1. Peserta }
$$$$
\text { memahami materi yang diberikan. }
$$

2 Peserta mampu menyelesaikan latihan yang ada di dalam modul.

3. Peserta antusias meminta pelatihan lanjutan. Berdasarkan tanggapan, respon, dan partisipasi dari peserta dapat diambil kesimpulan bahwa peserta merasa puas atas kegiatan yang diselenggarakan dan berharap akan adanya pelatihan lanjutan.

Berdasarkan respon positif peserta yang telah dikumpulkan oleh tim, peserta sangat berharap akan adanya pelatihan lanjutan untuk lebih meningkatkan kemampuan karyawan dalam membuat desain gambar dan tulisan sebagai media promosi dengan memakai bantuan Adobe Photoshop. 
Harapan yang lain adalah mempertahankan kerjasama yang telah dibina oleh tim pengabdian masyarakat Institut Bisnis dan Informatika Stikom Surabaya dengan kedua mitra yaitu Toserba Gandung dan Sopongiro Surabaya

\section{DAFTAR PUSTAKA}

1. Buchari. (2008). Manajemen Pemasaran dan Pemasaran Jasa. Bandung: CV Alfabeta.

2. Hedynata, \& Radianto. (2016). Strategi Promosi Dalam Meningkatkan Penjualan Luscious Chocolate Potato Snack. PERFORMA: Jurnal Manajemen dan Start-Up Bisnis, Volume 1, Nomor 1, April 2016.

3. Kotler, \& Armstrong. (1998). DasarDasar Pemasaran. Edisi V Jilid 2 Prentice Hall, Jakarta.

4. Kotler, \& Armstrong. (2012). Marketing management (14th ed.). New Jersey, US: Pearson Education, Inc.

5. Kotler, P. (1997). Manajemen Pemasaran. Jakarta: Alih bahasa Hendra Teguh dan Ronny Antonius, Prenhallindo.

6. Lamb. (2009). Essentials of marketing (6th ed). Mason, US: South-Western Cengage Learning.

7. Medyawati, \& dkk. (2000). Mini Shop Management : Merchandising and Inventory. Universitas Gunadarma, Depok.

8. Paramita. (2012). Pengaruh Aplikasi Bauran Pemasaran Terhadap Kepuasan Pelanggan Toko Modern (Studi Kasus Pada Carrefour di Depok).

9. Rayana. (2009). Prospek Ritel Modern Masih Menjanjikan. Diambil Kembali dari Road To Success (Growth Innovation Leadership).

10. Shofiah. (2000). Bisnis Eceran Tradisional di Tengah Bisnis Eceran Modern. Kebi STIEKERS, 76-81.

11. Tambunan, T., \& dkk. (2004). Kajian Persaingan dalam Industri Retail. Komisi Pengawas Persaingan Usaha (KPPU).

12. Utomo, T. J. (2010). Lingkungan Bisnis dan Persaingan Bisnis Retail. STIE Pelita Nusantara Semarang. 